\title{
Brand Experience, Brand Image, and Brand Trust to Nike's Loyalty Brand in Jakarta
}

\author{
Rahelia Margaretha ${ }^{1}$, Rodhiah ${ }^{2}$ \\ ${ }^{1,2}$ Faculty of Economics and Business, Universitas Tarumanagara, Indonesia \\ rahelia.115180273@stu.untar.ac.id,rodhiah@fe.untar.ac.id
}

\begin{abstract}
The purpose of this study is to examine and determine the influence of brand experience, brand image, and brand trust on brand loyalty Nike in Jakarta. The research design used in this study is quantitative method with a descriptive approach. Sampling was carried out using a non-probability sampling method with a convenience sampling approach with a total sample 123 respondents who are Nike user in Jakarta. Data collection method is done by distributing online questionnaires. Data analysis techniques used is partial least square-structural equation modeling (PLS-SEM) and using SmartPLS version 3. The results of this study indicate that brand experience, brand image and brand trust can have a positive influence on brand loyalty.
\end{abstract}

\section{Keywords}

brand experience; brand image; brand trust; brand loyalty

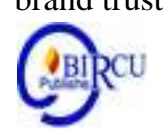

\section{Introduction}

In this era, there are many changes in lifestyle among Indonesian people, especially teenagers. Lifestyle becomes an identity that is attached to society. The factor that can support lifestyle changes is technology. With the technology can make it easier for people to get a product or service. Sophisticated technology can also make it easier for companies to create a large number of products and quickly with good quality. This is what can make companies compete to create quality products and try to instill these products in the minds of consumers. An example is sportswear. In Indonesia, there are various sports clothing brands such as Adidas, Rebook, Puma, Skechers, Nike and many more. The number of competitors who offer products in the field of sportswear requires Nike to continue to create something new and innovative in order to remain a market leader and increase brand loyalty in the minds of consumers.

Marketing is a process of planning and execution, starting from the conception stage, pricing, promotion, to the distribution of goods, ideas and services, to make exchanges that satisfy the individual and his institutions (Dianto in Asmuni et al, 2020). According to Tjiptono in Marlizar (2020) marketing performance is a function that has the greatest contact with the external environment, even though the company only has limited control over the company's environment. In the world of marketing, consumers are assets that must be maintained and maintained their existence in order to remain consistent with the products we produce (Romdonny and Rosmadi, 2019).

Brand loyalty has an important influence in a company's marketing, it can help companies make profits, by understanding brand loyalty, companies can ensure their customers will continue to buy even if the price or characteristics of the product change (June-Hyuk Kwon et al., 2020). A brand will be said to be successful if its customers express satisfaction with the brand by buying it continuously. Ong et al. (2018) said that brand experience has a positive and significant influence on brand loyalty. Brand experience is the result of stimulation that triggers consumers to use a brand, thus 
customers will be encouraged to repeat the experience often and will continue to buy it (Ong et al., 2018). Wu \& Wang (2014) stated that brand image can represent a company's public image and can be seen through evaluation and consumer awareness of the company or brand in the market. The results of research conducted by Sahin et al., (2011) and Laroche et al., (2012) found that brand trust has a positive influence on brand loyalty. Brand trust is the main determinant of brand loyalty. The way consumers show their trust in a product is by making repeated purchases.

This study seeks to find out about the influence of Nike sportswear consumer brand loyalty by using several variables which the researchers consider to be able to influence brand loyalty. The related variables are the brand experience felt by consumers who use Nike, the brand image contained in the memories of Nike consumers and brand trust which is contained in the consumer's belief that Nike will carry out the expected and needed functions. The variables in this study were adopted from previous studies. In a previous study researched by Chao-Chin Huang (2017) the variables used are brand experience, brand loyalty, using brand love and brand trust mediation. This research was carried out again because differences were still found such as variables, research subjects, research objects, and places.

\section{Review of Literature}

\subsection{Brand Experience}

Altaf et al. (2017) said that brand experience is known as a general term that includes all consumer products, shopping, services and experiences in using the brand. Meanwhile, Lee and Kang (2012) explain that brand experience is a consumer experience as an insight formed when interacting with all brands. So it can be concluded that brand experience is the experience felt by consumers about a particular product in direct or indirect interaction situations.

\subsection{Brand Image}

Kotler and Keller (2016) say assumptions about a brand will be reflected by consumers based on their memories. Keller (2013) says that brand image is a consumer's perception of a brand. It can be said that brand image is a person's perception of a brand that is in the consumer's memory and can influence the purchase of a brand.

\subsection{Brand Trust}

Zhou et al. (2012) define brand trust as the extent to which consumers believe in a particular brand and have confidence in that brand. According to Emilia and Rodhiah (2020) "customers will feel safe using a brand because they already have trust in the brand and can rely on the brand in fulfilling their obligations as a brand". So it can be concluded that brand trust is the ability of a brand to be trusted because it can meet consumer needs and can carry out the functions desired by consumers.

\subsection{Brand Loyalty}

Pappu and Quester (2016) say that brand loyalty is a measure given by customers to a preferred brand, motivating customers to make repeat purchases of the brands they like. According to Thompson et al. (2014) said that brand loyalty is a consumer's attitude to prefer a brand from previous shopping experiences as measured by repurchase for the same brand. So it can be concluded that brand loyalty is a measure given by customers to buy the same brand continuously in the future even though there are better offers from competing brands. 


\subsection{The Link between Brand Experience and Brand Loyalty}

Ong et al. (2018) explains that brand experience is the result of a stimulus given by a brand that can trigger enjoyment from consumers, thus, customers will be encouraged to often repeat the experience from time to time. Iglesias et al (2011) explained that if consumers have a positive and pleasant experience about a product, they are likely to repeat to buy and develop brand loyalty.

\subsection{The link between Brand Image and Brand Loyalty}

Rido and Wibowo (2016) say that through brand image consumers can identify products, evaluate products and gain experiences that lead to brand loyalty. Saleem et al. (2015) said that the brand image is in the minds of customers. For example, when a company promises to provide good quality to increase loyalty, the support of the brand image is important.

\subsection{The link between Brand Trust and Brand Loyalty}

June-Hyuk Kwon et al. (2020) says that loyalty is a relationship created by trust, and is associated with purchase intention. In trust, consumers must demonstrate a commitment to obtain valuable goods and lead to repeat purchases. Chao-Chin Huang (2017) says it is clear that customer loyalty must develop over time when trust in a brand has accumulated. Based on the explanation above, the researchers created a research model to clarify the relationship between brand experience, brand image, and brand trust on brand loyalty.

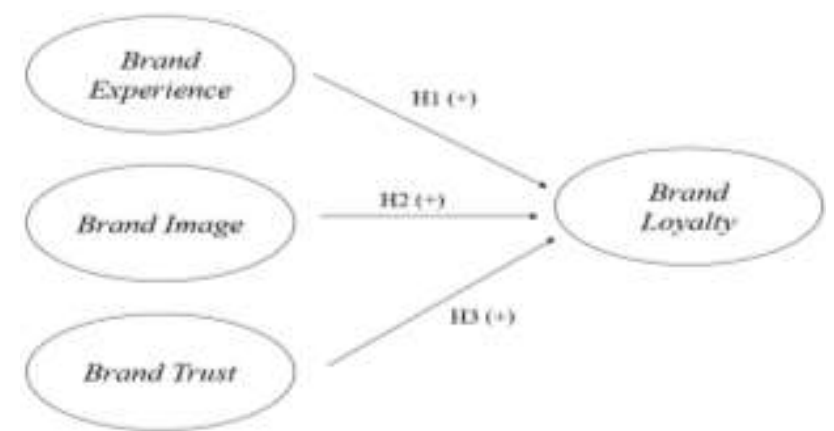

Figure 1. Research Model

The research hypothesis is as follows:

H1: Brand Experience has a positive influence on Brand Loyalty.

$\mathrm{H} 2$ : Brand Image has a positive influence on Brand Loyalty.

H3: Brand Trust has a positive effect on Brand Loyalty.

\section{Research Method}

The population of this research is all Nike users who live in Jakarta. This study uses a non-probability sampling technique with a convenience sampling technique where the researcher selects a sample of people who are easy to find and are considered capable of providing the required information. The number of samples studied were 123 respondents. The data collection technique used a questionnaire distributed online using a google form to respondents who have or are currently using Nike in Jakarta. In this study, the variables studied include brand experience, brand image, brand trust and brand loyalty. The data processing of this research uses PLS-SEM software which consists of two analyzes, namely the outer model and the inner model. 


\section{Results and Discussion}

\subsection{Results}

\section{Respondent Profile}

Based on data on respondent characteristics, the majority of respondents are women (65.9\%), age 21-30 years (56.9\%), domiciled in West Jakarta (50.4\%), Last Education SMA/SLTA $(69.1 \%)$, and Student Work $(83.7 \%)$.

a. Outer Model

1. Convergent Validity

Table 1. Validity Test Results - Average Variance Extracted (AVE) Variabel Average Variance Extracted (AVE)

\begin{tabular}{cc}
\hline Brand Experience & 0,656 \\
\hline Brand Image & 0,602 \\
\hline Brand Loyalty & 0,663 \\
\hline Brand Trust & 0,625 \\
\hline
\end{tabular}

It is known that the AVE value of each variable has a value above 0.5 so that it meets the requirements and criteria of convergent validity.

2. Discriminant Validity

Table 2. Validity Test Results - Cross Loading

\begin{tabular}{ccccc}
\hline & Brand Experience & Brand Image & Brand Loyalty & Brand Trust \\
\hline BE4 & $\mathbf{0 , 7 6 4}$ & 0,535 & 0,650 & 0,473 \\
\hline BE5 & $\mathbf{0 , 7 1 2}$ & 0,559 & 0,533 & 0,575 \\
\hline BE6 & $\mathbf{0 , 9 0 9}$ & 0,618 & 0,648 & 0,607 \\
\hline BE7 & $\mathbf{0 , 8 4 1}$ & 0,589 & 0,715 & 0,593 \\
\hline BI3 & 0,503 & $\mathbf{0 , 7 6 6}$ & 0,562 & 0,555 \\
\hline BI4 & 0,380 & $\mathbf{0 , 7 0 7}$ & 0,530 & 0,505 \\
\hline BI5 & 0,533 & $\mathbf{0 , 7 0 7}$ & 0,544 & 0,564 \\
\hline BI6 & 0,679 & $\mathbf{0 , 8 0 1}$ & 0,632 & 0,630 \\
\hline BI7 & 0,630 & $\mathbf{0 , 8 8 5}$ & 0,701 & 0,672 \\
\hline BL1 & 0,588 & 0,525 & $\mathbf{0 , 7 9 5}$ & 0,610 \\
\hline BL2 & 0,603 & 0,606 & $\mathbf{0 , 7 9 1}$ & 0,597 \\
\hline BL3 & 0,618 & 0,649 & $\mathbf{0 , 8 2 9}$ & 0,707 \\
\hline BL4 & 0,575 & 0,637 & $\mathbf{0 , 7 9 7}$ & 0,584 \\
\hline BL5 & 0,742 & 0,698 & $\mathbf{0 , 8 7 8}$ & 0,647 \\
\hline BL6 & 0,685 & 0,593 & $\mathbf{0 , 8 3 2}$ & 0,598 \\
\hline BL7 & 0,685 & 0,664 & $\mathbf{0 , 7 7 1}$ & 0,673 \\
\hline BT1 & 0,548 & 0,599 & 0,605 & $\mathbf{0 , 8 0 1}$ \\
\hline BT2 & 0,515 & 0,545 & 0,553 & $\mathbf{0 , 7 9 1}$ \\
\hline BT3 & 0,576 & 0,616 & 0,596 & $\mathbf{0 , 7 2 1}$ \\
\hline BT4 & 0,539 & 0,654 & 0,597 & $\mathbf{0 , 8 1 3}$ \\
\hline BT6 & 0,502 & 0,578 & 0,572 & $\mathbf{0 , 8 0 7}$ \\
\hline BT7 & 0,589 & 0,598 & 0,730 & $\mathbf{0 , 8 0 6}$ \\
\hline & & & &
\end{tabular}


It is known that the loadings value of each indicator in each variable is greater than the other variables so that it meets the requirements and criteria of discriminant validitycross loading.

3. Reliability

Table 3. Reliability Test Results

\begin{tabular}{ccc}
\hline & Cronbach's Alpha & Composite Relibiality \\
\hline Brand Experience & 0,822 & 0,883 \\
\hline Brand Image & 0,833 & 0,882 \\
\hline Brand Loyalty & 0,915 & 0.932 \\
\hline Brand Trust & 0,880 & 0,909 \\
\hline
\end{tabular}

\section{b. Inner Model}

1. Coefficient of Determination Test $\left(\mathrm{R}^{2}\right)$

The coefficient of determination test was conducted to determine the level of strength of the contribution between variables.

Table 4. $\mathrm{R}^{2}$ Test Results

\begin{tabular}{ccc}
\hline & R Square & R Square Adjusted \\
\hline Brand Loyalty & 0,751 & 0,745 \\
\hline
\end{tabular}

Based on table 4, the variables of brand experience, brand image and brand trust can predict brand loyalty and have a value of 0.751 and have a strong category. So that $100 \%$ reduced by $75.1 \%$ is $24.9 \%$ and can be explained by other variables not examined in this study.

2. Predictive Relevance $\left(\mathrm{Q}^{2}\right)$

Predictive relevance is done to find out how well the results of the variable indicator

Table 5. Predictive Relevance Test Results

\begin{tabular}{cccc}
\hline & SSO & SSE & $\mathbf{Q}^{\mathbf{2}}$ \\
\hline Brand Loyalty & 861.000 & 444.690 & 0,484 \\
\hline
\end{tabular}

Based on table 5, it is known that the value of $\mathrm{Q}^{2}$ is 0.484 which means that $\mathrm{Q}^{2}$ has a value above zero $(0)$ so that it can predict the model well.

\section{Effect Size Analysis $\left(\mathrm{f}^{2}\right)$}

Effect size analysis is used to find out how the variables predict the effects in the structural model and how big the effect is in the research model.

Table 6. Effect Size Analysis Test Results (f $\left.{ }^{2}\right)$

\begin{tabular}{cc}
\hline & Brand Loyalty \\
\hline Brand Experience & 0,282 \\
\hline Brand Image & 0,092 \\
\hline Brand Trust & 0,145
\end{tabular}


Based on table 6, it can be concluded that the brand experience variable has the greatest change effect on brand loyalty with a value of 0.282 , then the brand trust variable has a moderate change effect on brand loyalty with a value of 0.145 and the brand image variable has the most small effect to brand loyalty with a value of 0.092 . So it can be concluded that the results of the effect size test explain that the variables in this study have an effect.

\section{Path Coefficient}

Path coefficient test is done to test the relationship between variables.

Table 7. Path Coefficient Results

\begin{tabular}{cccc}
\hline & Original Sample & T Statistics & P Values \\
\hline Brand Experience $\rightarrow$ Brand Loyalty & 0,399 & 4,647 & 0,000 \\
\hline Brand Image $\rightarrow$ Brand Loyalty & 0,252 & 2,145 & 0,032 \\
\hline Brand Trust $\rightarrow$ Brand Loyalty & 0,309 & 3,071 & 0,002 \\
\hline
\end{tabular}

Based on table 7 shows that brand experience has a positive direction or relationship to brand loyalty; brand image has a positive direction or relationship to brand loyalty; and brand trust has a positive direction or relationship to brand loyalty.

\subsection{Discussion}

The hypothesis testing shows that hypothesis 1 is not rejected, which means that the Brand Experience variable has a positive influence on the Brand Loyalty variable. This shows that the higher the brand experience, the higher the brand loyalty of the product. The results of this study are in line with previous research conducted by Ong et al. (2018), Brakus et al. (2009) and Kang et al. (2017). Hypothesis 2 is not rejected, which means that the Brand Image variable has a positive influence on the Brand Loyalty variable. This shows that the higher the brand image, the higher the brand loyalty of the product. The results of this study are in line with previous research conducted by Ike-Elechi and Zhenzhen Tan (2009) and Saleem et al. (2015). Hypothesis 3 is not rejected, which means that the Brand Trust variable has a positive influence on the Brand Loyalty variable. This shows that the higher the brand trust, the higher the brand loyalty of the product. The results of this study are in line with previous research conducted by Richard Chinomona (2014), June-Hyuk Kwon et al. (2020) and Chao-Chin Huang (2017).

\section{Conclusion}

Based on the results of research and discussion that have been carried out, it can be concluded that brand experience, brand image, and brand trust have a positive and significant influence on the brand loyalty of Nike customers in Jakarta. 


\section{References}

Altaf, M., Iqbal, N., Mohd. Mokhtar, S. S., \& Sial, M. H. (2017). Managing consumerbased brand equity through brand experience in Islamic banking, Journal of Islamic Marketing, 8(2), 218-242.

Asmuni, et al. (2020). Implementation of the principle of sale and purchase transactions through MLM in Brand Branch (BC) PT. Herba Penawar Alwahida Indonesia (HPAI) Tanjungbalai. Budapest International Research and Critics Institute-Journal (BIRCI-Journal) Volume 3, No. 4, Page: 3376-3385

Chao-Chin Huang. (2017), "The impacts of brand experiences on brand loyalty: mediators of brand love and trust", Journal of Australian Management, Vol. 55 No.5, pp. 915934.

Emilia Machado and Rodhiah. (2020). "Pengaruh self-expression dan brand trust terhadap electronic-word of mouth dengan brand love sebagai mediasi pada konsumen vans di Jakarta". Jurnal Muara Ilmu Ekonomi dan Bisnis. Vol.5, No.1, 49-58.

Hair, Joseph F Jr., Hult, G. Tomas M., Ringle, Christian M., \& Sarstedt, M. (2017). A Primer on Partial Least Squares Structural Equation Modeling (PLS-SEM).

Hamid, M.R.Ab, Samin, W., \& Sidek, M.H. Mohmad (2017). Journal of Physics: Conference Series. Discriminant Validity Assessment: Use of Fornell \& Larcker criterion versus HTMT Criterion.

Iglesias, O., Singh, J.J. and Batista-Foguet, J.M. (2011), "The role of brand experience and affective commitment in determining brand loyalty", Journal of BrandManagement, Vol. 18No. 8, pp. 570-582.

June-Hyuk et al., (2020). "Antecedent factors that affect restaurant brand trust and brand loyalty: focus on US and Korean consumers. Journal of Product \& Brand Management, pp. 559-572.

Keller, Kevin Lane. (2013). Strategic Brand Management. United States of America. Pearson Education Limited.

Laroche, M., Habibi, M.R., Richard, M.O. and Sankaranarayanan, R. (2012), "The effects of social media based brand communities on brand community markers, value creation practices, brand trust and Brand loyalty", Computers in Human Behavior, Vol. 28 No. 5, pp. 1755-1767.

Lee, H.J. and Kang, M.S. (2012), "The effect of brand experience on brand relationship quality", Academy of Marketing Studies Journal, Vol. 16 No. 1, pp. 87-98.

Marlizar, et al. (2020). The Role of Market Orientation and Creativity in Affecting the Marketing Performance of Market Traders in Aceh Market Banda Aceh City. Budapest International Research and Critics Institute-Journal (BIRCI-Journal).P. 1114-1127

Ong, C.H., Wei Lee, H. and Ramayah, T. (2018), "Impact of brand experience on loyalty", Journal of Hospitality Marketing and Management, Vol. 27 No. 7, pp. 755-774.

Pappu, R. and Quester, P.G. (2016), "How does brand innovativeness affect brand loyalty?", European Journal of Marketing, Vol. 50 Nos 1-2, pp. 2-28.

Rido, E., \& Wibowo, S. (2016). Pengaruh Experiental Marketing, Emotional Branding dan Citra Merek terhadap Loyalitas Merek (Survei Konsumen Operator Simpati di Yogyakarta), 7(2), 158-169.

Romdonny, J., Rosmadi, M. L. N. (2019). Factors Affecting Customer Loyalty in Products. Budapest International Research and Critics Institute-Journal (BIRCI-Journal) Volume 2, No 1, Page: 337-343 
Sahin, A., Zehir, C. and Kitapçı, H. (2011), "The effects of Brand experiences, trust and satisfaction on building Brand loyalty: an empirical research on global brands", Procedia - Social and Behavioral Sciences, Vol. 24, pp. 1288-1301.

Saleem, S., Rahman, S. u., \& Omar, R. M., (2015), "Measuring customer based beverage brand equity: investigating the relationship between perceived quality, brand awareness, brand image, and brand loyalty". International Journal of MarketingStudies 7(1), 66-77.

Thompson, F.M., Newman, A. and Liu, M. (2014), "The moderating effect of individual level collectivist values on brand loyalty", Journal of Business Research, Vol. 67 No. 11, pp. 2437-2446.

Wu, S.-I., \& Wang, W.-H. (2014). Impact of CSR perception on brand image, brand attitude and buying willingness: A study of a global cafe' . International Journal of Marketing Studies, 6(6).

Zhou, Z., Zhang, Q., Su, C. and Zhou, N. (2012), "How do brand communities generate brand relationships? Intermediate mechanisms", Journal of Business Research, Vol. 65 No. 7, pp. 890-895. 